\title{
Muséologies
}

Les cahiers d'études supérieures

\section{New Mediation Practices as a trope for Social Change. The cases of Tate Modern, Tensta Konsthall and Clark House Initiative}

\section{Luísa Santos}

Volume 8, numéro 2, 2016

Les nouveaux paradigmes

URI : https://id.erudit.org/iderudit/1050766ar

DOI : https://doi.org/10.7202/1050766ar

Aller au sommaire du numéro

Éditeur(s)

Association Québécoise de Promotion des Recherches Étudiantes en Muséologie (AQPREM)

ISSN

1718-5181 (imprimé)

1929-7815 (numérique)

Découvrir la revue

Citer cet article

Santos, L. (2016). New Mediation Practices as a trope for Social Change. The cases of Tate Modern, Tensta Konsthall and Clark House Initiative. Muséologies, 8(2), 159-176. https://doi.org/10.7202/1050766ar

Tous droits réservés ( Association Québécoise de Promotion des Recherches Étudiantes en Muséologie (AQPREM), 2018
Ce document est protégé par la loi sur le droit d'auteur. L’utilisation des services d'Érudit (y compris la reproduction) est assujettie à sa politique d'utilisation que vous pouvez consulter en ligne.

https://apropos.erudit.org/fr/usagers/politique-dutilisation/ 
Article six

New Mediation Practices as a trope for Social Change. The cases of Tate Modern, Tensta Konsthall and Clark House Initiative

Luísa Santos 


\section{Luísa Santos is Assistant Professor at the Faculty of} Human Sciences of Universidade Católica, in Lisbon, since 2016, with a Gulbenkian Professorship. She holds a PhD in Cultural Studies, Humboldt-Viadrina School of Governance, Berlin (2015), with a scholarship from The Foundation for Science and Technology (FCT), a MA in Curating Contemporary Art, Royal College of Art, London (2008), with a Gulbenkian Scholarship, and a Degree in Communication Design, Faculty of Fine Arts-University of Lisbon (2003). In 2012 she conducted research in Curatorial Practice at the Konstfack University College of Arts, Crafts and Design, Stockholm (2012).

Combining research with curatorial practice, her most recent activities include the scientific and artistic co-coordination of a European project co-financed by Creative Europe (coordinated at Universidade Católica Portuguesa) titled "4Cs: from Conflict to Conviviality through Creativity and Culture" (2017-2021); curatorship of exhibitions such as "Tension \& Conflict: video-art after 2008", MAAT; (2017); "There's no knife without roses", Tensta Konsthall, Stockholm (2012); "Daqui parece uma montanha" , Modern Art Centre, Calouste Gulbenkian Foundation, Lisbon (2014); "Græsset er altid grønnere", Museet for Samtidskunst, Roskilde (2014-15) and the executive curatorship of the first edition of Anozero: Coimbra Biennial of Contemporary Art (2015).

Since 2015, she is a member of the Scientific Committee of the International Congress CSO and the Scientific and Editorial Committees of the Peer Reviewed Academic Publications Estúdio, Gama and Croma. Since 2016, she is a member of the Editorial Board of the Yearbook of Moving Image Studies (YoMIS), published by Büchner-Verlag.

Website: http://luisa-santos.weebly.com/ 


\section{Introduction: Art changes, we change}

When the new extension of the Tate Modern in London opened on June 16, 2016, posters announced the new identity of the museum with the headline "Art changes, we change." Throughout history, art has always reflected the world we live in. Contemporary times are filled with changes and challenges such as social and economic crisis, the massive flow of migrants and refugees arriving from diverse war theatres, and climate change, to name a few.

Artists experience social, economic and political change and change with it. Most artists do not work in closed studios anymore: there are artists who witness and participate in the daily reality of war; artists who are social activists; artists who use their work as a way to communicate and address social change; artists who invite a wider participation from all citizens; artists who make critical observations; and artists who choose to take part in small and big revolutions. When they reflect the world we live in, artists make work that has the power to evoke a response and potentially lead to social change.

In the Manifesto for an Independent Revolutionary Art, André Breton and Diego

Rivera, under two totalitarian political regimes-German fascism and Russian Stalinism-argued that art can have an effect in society and be revolutionary only if it becomes independent of any social constructs: "True art, which is not content to play variations on ready-made models but rather insists on expressing the inner needs of man and of mankind in its time- true art is unable not to be revolutionary, not to aspire to a complete and radical reconstruction of society.” 1
Almost 50 years later, in the rise of what became known as "relational aesthetics,"2 Dan Graham wrote: "All artists are alike. They dream of doing something that's more social, more critical, and more real than art." This text was the caption of his work Two-way Mirror Punched Steel Hedge Labyrinth (1994), in the exhibition held at the Minneapolis Sculpture Garden, Walker Art Center, in Minneapolis, in 1998.

If we think of art as a social system-an idea coined by German sociologist Niklas Luhmann, in his seminal work Soziale Systeme: Grundriß einer allgemeinen Theorie, ${ }^{3}$ which puts art in the domain of perception-we will understand art in terms of what it does at its best: showing various possible realities, alternatives to the ways we look at the world we live in, at the social, economic and political levels. ${ }^{4}$ With a focus on the social, economic and political domains of life, contemporary art seems to operate in the area of critical analysis grounded in images, objects and whatever best fits a possible visual translation of such immersion. Authors such as Peter Osborne, who follows the post-Kantian European tradition that focuses on a very small number of paradigmatic works that aim to embody diverse key aspects of characteristically contemporary life, have been tackling this idea in relation to mediation. Osborne identified "the crisis of mediations" as pivotal in contemporary art. This crisis, for Osborne, emerges as a manifestation of a long-term process of social changes. Such changes translate and institutionalize the idea of freedom as the unconstrained expression of the individual. Simultaneously, art would be the ultimate expression of freedom. Osborne's thought seems to be twofold: on one hand, an artistic medium's practice implies a historical context and continuity, which suggests that such practice cannot be understood as an echo of the particular current social

3 LUHMANN, Niklas. Soziale Systeme: Grundrißeiner allgemeinen Theorie, Berlin: Suhrkamp Verlag, 1984. 4 LIND, Maria, "Keynote speech", Curating the Most beautiful Kunshtalle in the world, Como: Antonio Ratti Foundation, 21. November. 2011
1 Marxist Literary Criticism. Manifesto for an Independent Revolutionary Art. https://www.marxists.org/subject/art/ lit_crit/works/rivera/manifesto.htm, Retrieved July 2016. 2 BOURRIAUD, Nicolas. Esthétique relationnelle. Dijon: Les Presses du réel, 1998. 
conditions where it was produced and, on the other hand, that in order to be critical, art must reflect the social conditions in which it exists (in other words, it should translate the result of an immersion in the social conditions where it is produced and presented). ${ }^{5}$

\section{According to ICOM:}

"A museum is [defined as] a non-profit, permanent institution in the service of society and its development, open to the public, which acquires, conserves, researches, communicates and exhibits the tangible and intangible heritage of humanity and its environment for the purposes of education, study and enjoyment." 6

In their "service of society," art museums reflect the concerns and ideas raised by art. From playing the role of local players in the neighbourhoods in which they are created, to serving as platforms for participation and exchange of ideas around the issues of our time, museums are doing what art does at its best: reflecting and acting upon the world we live in. These ideas have been widely studied in the last ten years by curators and museum directors such as Claire Bishop, Nicholas Serota and Nina Simon. In her Radical Museology, Claire
Bishop argues that museums of contemporary art nowadays build an environment where experimenting with perception of life (in its social, economic and political domains) in the present becomes a tool to rethink the future. ${ }^{7}$ The Tate, under the directorship of Nicholas Serota, has been developing a series of events and studies on "tomorrow's art museums." These studies are highly participatory: from courses to workshops, Tate has been gathering ideas and contributions from the international art community. Two months after the opening of the extension of Tate Modern, "Tate Intensive: Making Tomorrow's Art Museums"9 put together 30 museum professionals from different art institutions-from Brazil, China, South Korea, Russia, Greece, Portugal, Australia, New Zealand, Canada, the US, India and the UK - to discuss the challenges and the potential of museums in the 21 st century. Nina Simon's "The Participatory Museum"10 is a book and a website analyzing the processes of audience participation in museums. With a theoretical account of participatory art practices, Nina Simon attempts to provide a series of guidelines for good mediation practices in museums while "inviting people to actively engage as cultural participants, not passive consumers." 11
5 OSBORNE, Peter. Anywhere Or Not At All: Philosophy of Contemporary Art, London: Verso, 2013

6 ICOM, ICOM Definition of a Museum. http://archives. icom.museum/definition.html Retrieved February 2017

7 BISHOP, Claire. Radical Museology or, What's

Contemporary in Museums of Contemporary Art? London: Koenig Books, 2013

8 In 2006, ten years before the opening of Tate Modern's extension, Nicholas SEROTA published his Experience or Interpretation: The Dilemma of Museums of Modern Art, which reflected on mediation practices of today's museums. In 2009, Nicholas SEROTA gave a lecture at the London School of Economics titled "The Museum of the 21st Century" and, in 2016, under his directorship and coinciding with the period before and during the opening of Tate Modern's extension, courses, conferences and meetings were held at Tate Modern and Tate Britain. These included Towards Tomorrow's Museum (2015) and Tate Intensive: Making Tomorrow's Art Museums (2016). In 2005 and in 2015, two articles were published in Tate etc. Magazine tackling the challenges of the museums of contemporary art: "The Museum of Tomorrow," by Hans Ulrich OBRIST ( Tate etc. issue 5, Autumn 2005) and Chris
DERCON's "What is the museum of the future?" (Tate etc. issue 35, Autumn 2015). Chris Dercon's text counted on contributions of several artists and museum professionals who gave their definitions of the museum of the future. Another example of the studies and experiments on the future of museums, undertaken by Tate, under the directorship of Nicholas SEROTA, was the exhibition "An Imagined Museum: works from the Centre Pompidou, Tate and MMK collections" (2015-16), at Tate Liverpool. Highly participatory, the exhibition ended in a performance titled "2053: A Living Museum." All the artworks were gone, and the audience was invited to personally recollect the missing art works-this would then become the Museum of 2053. 9 TATE. Tate Intensive: Making Tomorrow's Art Museums. http://www.tate.org.uk/whats-on/tate-modern/courses-andworkshops/tate-intensive-making-tomorrows-art-museum Retrieved January 2017

10 THE PARTICIPATORY MUSEUM. The Participatory Museum. http://www.participatorymuseum.org/ Retrieved January 2017 11 SIMON, Nina. The Participatory Museum. Museum 2.0., 2010. 
What these studies and experiments have in common is a focus on new mediation practices reflecting a fresh trend in museums in which they are reshaping their new place in the contemporary world.

This is precisely the focus and theme of this article: to deliver an account of the evolution of museums' mediation practices through three examples. Tate Modern (United Kingdom), Tensta Konsthall (Sweden) and Clark House Initiative (India) will serve as points of reflection on experimentations that might point to a possible future of art museums in their role in an ever-changing contemporary society.

The article begins with an historical contextualization of curatorial practices from the exhibition-making of Harald Szeemann ${ }^{12}$ and Pontus Hultén to the new institutionalism as defined by Jonas Ekeberg. ${ }^{13}$ This brief historical account shows a moving away from the star curator to a new lexicon characterized by blurring the boundaries between practice and research, individual and collective, which translates to mediation practices and experiments. Tagny Duff defines the idea of star curator as a potential danger - curators can become the identity of their exhibitions, rather than the exhibiting artists. Authors such as Hal Foster and Claire Bishop have also noted this risk. ${ }^{14}$

Art institutions' and curators' tropes do not seem to be too different from the artists' tools. Paul Couillard, an artist, writer and curator, describes the starting point of his practice as an artist as creation of situations. On a panel titled "Metamorphosis: The Artist as Curator," InFest, Vancouver, in 2004, he noted that

12 MÜLLER, Hans-Joachim. Harald Szeemann. Exhibition Maker, Ostfildern-Ruit: Hatje Cantz Verlag, 2006.

13 EKEBERG, Jonas (Ed.). New Institutionalism, Versted\#1, Oslo: Office for Contemporary Art, 2003.

14 "When the institution may overshadow the work that it otherwise highlights, it becomes a spectacle. It collects the cultural capital, and the director/curator becomes the star." (Hal Foster, "The Artist as Ethnographer," from The Return of the Real, 1981. Quoted in Claire Bishop, "Antagonism and Relational Aesthetics,” October 110, p. 52, 2004. Quoted in Tagny Duff, "Performing the Curator: Staging Unstable Relations," AGYU, 2005).
Matthew Higgs (ICA), who is also an artist and a curator, defines his curatorial practice in the same way. In the abstract "Curating as Art Making," (AGYU, 2005), Couillard defines "a curatorial project, like most performative work, sets up a situation of inter-relationships in time and space. Viewing artist/curator as a hybrid practice seems a natural extension of the rhetoric of artist-directed activity upon which the Canadian artist-run centre network was formed. ${ }^{15}$ According to Andrew Paterson, Couillard's definition of what is performance art and what is not, and how this practice can be compared to curating, expands to Nicolas Bourriaud's idea of "relational aesthetics."16

Similarly, what observation of the three examples will tell is that the experiments undertaken by new mediation practices in art institutionstropes such as total immersion in daily life and in society's challenges-are a consequence of the art production more than a specific strategy of art museums.

After the brief historical account, three examples of new mediation practices are given through three art institutions. Among these examples, only Tate is a museum in a strict sense. The extension of the notion of the museum to art institutions such as Tensta Konsthall and Clark House Initiative is employed to reflect emerging paradigms in museology, taking place both in museums and in art institutions of different sizes and scopes.

Throughout the article, narrative methods ${ }^{17}$ and the study and presentation of three examples are the chosen methodologies. Participation in events and direct observation

15 AGYU. Curating as Art Making. Paul Couillard. http:// commissairesencontexte.ca/en/talk.php?id=6, Retrieved February 2017

16 Curators in Context, Curation, Creation, Interpretation, Imagination, Many Other Nouns and Also Their Verbs. Andrew Paterson. http://curatorsincontext.ca/en/paterson_9.htm. Retrieved February 2017

17 BOJE, David, Narrative Methods for Organizational and Communication Research. London: Sage, 2001. 
of the selected institutions were applied in these methodologies: the author has participated in events and meetings such as "Tate Intensive: Making Tomorrow's Art Museums" at Tate Modern, July 2016. ${ }^{18}$ The author has also visited the three institutions under analysis and discussed mediation practices in relation to social change in each different cultural context of the corresponding institution. These discussions took the shape of a series of episodic interviews, as well as a seminar titled "There is no knife without roses," co-organised by Maria Lind and the author at Tensta Konsthall, in 2012. ${ }^{19}$

Narrative methods, following David Boje's theoretical framework, allow an open and subjective reading in opposition to the creation or agreement with grand narratives (ontologies). Narrative methods is a multi-voiced methodology that focuses on non-linear, almost living storytelling that is fragmented, polyphonic (many-voiced) and collectively produced. ${ }^{20}$

To get an unbiased outline, it is crucial to continually observe and analyze discussions of the arts community by turning from the abstract realm of ideas to the tangible field of practices,${ }^{21}$ hence the choice of presenting practical examples. The evolution of the new mediation practices and how their strategies are employed is then given by looking at three examples from the last ten years.
The article concludes with a brief note on the potential of new mediation practices as an institutional change responding to social and geopolitical transformations and, above all, to current artistic practices that increasingly invest the different spheres of social activities.

\section{A brief historical background: from exhibi- tion-making to new institutionalism}

Two examples of practices in the relationship between society, with its changes, and the reflections of art museums on it are those of Pontus Hultén (1924, Stockholm - 2006, Stockholm) and Harald Szeemann (1933, Bern - 2005, Canton Ticino).

Pontus Hultén was the director of the Moderna Museet in Stockholm, Sweden, from 1958 to 1973, and was one of the key authors involved in shaping the museum as an open space, which related to the ideas of multidisciplinarity, participation and collaboration.

The idea of open museum from the late 1960s and early 1970 s, tested and defended by curators and artists, originated from the concept of museum as platform, laboratory and discussion forum, ${ }^{22}$ a place to share knowledge from different discourses, which activates the creativity of the visitor, transforming the audience to active participant beyond the walls of the museum. ${ }^{23}$ The open museum was defined by Pontus Hultén ${ }^{24}$ as not merely a place to conserve works, which has lost its individual

22 The concept of museum forum was developed by

18 TATE, Tate Intensive: Making Tomorrow's Art Museums. http://www.tate.org.uk/whats-on/tate-modern/courses-andworkshops/tate-intensive-making-tomorrows-art-museum Retrieved January 2017 19 SCHOOL OF ARCHITECTURE. There's no knife without roses. https://www.arch.kth.se/en/kalender/ vad-gor-den-sociala-praktiken/vad-gor-den-sociala-praktiken-det-finns-ingen-kniv-utan-rosor-1.337584? date $=2012$ 09-29\&orgdate=2012-09-29\&length $=1$ \&orglength $=94$ Retrieved February 2017

20 BOJE, David. Narrative Methods for Organizational and Communication Research. London: Sage, 2001. 21 OGUT, Ahmet, "CCC: Currency of Collective Consciousness”, E-flux journal, nº 62, February 2015.
Duncan F. Cameron in his article "The Museum, A Temple or the Forum." (Cameron, 1972).

23 Mariana Roquette Teixeira, "Do ‘museu aberto' ao 'museu disperso': desafios ao poder,” MIDAS [Online], 6|2016, URL: http://midas.revues.org/1016; DOI: 10.4000/ midas.1016, Retrieved February, 2017.

24 The idea of open museum was often attributed to Pontus Hultén, but many curators and museum directors such as Harald Szeemann, Peter F. Althaus and Jean Leering, have contributed to its development (ROQUETTE Marianna Teixeira, “Do 'museu aberto' ao 'museu disperso': desafios ao poder,” MIDAS [Online], 6|2016, URL: http://midas.revues. org/1016; DOI: 10.4000/midas.1016, Retrieved February, 2017 
function, social and religious or public, but a place where artists find the audience and where the audience becomes its creator. ${ }^{25}$

In 1966, Hultén curated the famous exhibition "SHE - A Cathedral." It was a collaborative exhibition from the beginning, where he worked together with French artists Jean Tinguely and Niki de St. Phalle and the Swedish artist Per Olof Ultvedt. Daniel Birnbaum describes the exhibition as "a gigantic, lurid cathedral in the form of a supine woman that viewers could walk into, the entry being between her legs. Inside, visitors found an aquarium full of goldfish, a love seat for couples, a bar, a small cinema showing a Greta Garbo movie, a playground with a slide, and many other surprises. Green and red lights controlled the traffic through the vaginal entrance." ${ }^{26}$ The visitors' meeting with SHE - A Cathedral implied entering the sculpture, which in this case was both an artwork and an exhibition with a program rejecting the boundaries "between artworks and related programming." ${ }^{27}$ This process, which implied that the work was completed only through the interaction of the audience, recalls the Beuysian idea of social sculpture, in which everyone is an artist and holds the creative power of shaping and changing society: "This most modern art discipline-Social Sculpture/Social Architecture will only reach fruition when every living person becomes a creator, a sculptor, or architect of the social organism. Only then would the insistence on participation of the action art of FLUXUS and Happening be fulfilled; only then would democracy be fully realized." 28
In 1967, Hultén worked at the Kulturhuset for the city of Stockholm, where public participation was developed through workshops in which the public could participate and debate without the limitations that the press might face. It was intended as a space for looking at the world critically. In 1973, Hultén was appointed director of the Centre Pompidou, where he continued his vision of the open, participatory and multidisciplinary museum, putting together an orchestrated program with different disciplinary discourses including art, literature, film, science, theater and music, where concerts, debates and talks were as important to the overall program as exhibitions.

The first impulse, when thinking of the combination of different types of knowledge in a multidisciplinary project such as an open museum, might be to assume that some descriptions are in some sense better than others: more accurate, more complete or preferable on aesthetic, ethical or political grounds.

Using a visual example, when looking at Multistable Images, such as the famous image that can be seen as a duck or a rabbit, we see either one or another, but not two at same time. Yet the image cannot be reduced to either; it is neither only duck nor only rabbit, but duck and rabbit at the same time. The combination of simultaneity (seeing the same and various aspects in one image) and consecution (the sequence from seeing one aspect to seeing another) implies the acknowledgement and acceptance that both ways of seeing are correct either at the same time or both ways of seeing are correct when seen separately. Furthermore, the image forms no synthesis. ${ }^{29}$
25 SEROTA, Nicholas. 2000. Experience and Interpretation: The Dilemma of Museums of Modern Art. New York: Thames and Hudson. 26 BIRNBAUM Daniel, "Director of Intelligence," Artforum, February 2007, p. 61-62

27 MCDOWELL Tara, "Overture," The Exhibitionist, $\mathrm{n}^{\circ}$ 2, June 2010, p. 3
28 BEUYS Joseph, "I Am Searching For Field Character," 1973 (translated in: TISDALL Caroline, Art Into Society, Society Into Art, London: Institute of Contemporary Art, 1974. p. 48)

29 HOLZHEY, F. E., GRAGNOLATI, M., "Analogy and Difference: Multistable Figures in Pasolini's Notes for an African Oresteia, (BLASI D., GRAGNOLATI M., HOLZHEY F. E. eds.) The Scandal of Self-Contradiction, Berlin and Vienna: Verlag Turia + Kant, 2012, p.119-133. 
Such Multistable Images, in which it is possible to see different things and agree that both are correct, seem to be rare. Going back to multidisciplinarity, it is possible to combine knowledge and skills as well as perceptions from different disciplines and agree that all can be correct. While there is no reason to believe that alternatives should be possible for any recognised shape, in terms of looking at a Multistable Images but also in working in a multidisciplinary project, imagining other ways of seeing, experiencing and living, making them visible and realising them in various manners might be helpful to produce fruitful discussions and reach various possible conclusions instead of maintaining preconceived assumptions. On the other hand, even when images allow for several ways of viewing, each perceived form often relies not only on eliminating other potential shapes, but also on reducing the image's complexity, marking a few traits while ignoring others.

Each disciplinary discourse, like each social system, ${ }^{30}$ has the view of a complete reality in which nothing is missing, but none describes all of reality. While it is questionable whether it makes sense to posit here a pre-recognised reality (to apply the idea of Multistable Images), what seems to be clear is that the practice of shifting back and forth between different aspects and seeking to re-integrate elements recognised only from another perspective carries a productive potential. It may not lead to a better, fuller description, let alone to a synthesis, but does help in producing fruitful tensions on either side in contradistinction to an indifferent co-existence or violent conflict.

In his practice and through his experiments, Hultén demonstrated that curating means taking care of artworks in an expanded way. It is not only about preserving the works and presenting them in a passive way but also about communicating the ideas of art in the best ways possible, and that means, in many

30 LUHMANN, Niklas. Soziale Systeme: Grundriß einer allgemeinen Theorie, Berlin: Suhrkamp Verlag, 1984. cases, on one hand, putting art together with other disciplinary discourses with the internal tensions that might lead to and, on the other hand, speaking about our society using the same creative, participatory, practical and discursive methodologies as art itself.

Harald Szeemann was also a key figure in the re-shaping of art museums during the geopolitical and cultural changes that characterized the postwar period. Seeing himself as an exhibition-maker, in 1969 he organized the exhibition that would grant him the international recognition he enjoys today, with a work that has been regarded as a major source of inspiration by ensuing generations of curators: "When Attitudes Become Form," at the Bern Kunsthalle, in Switzerland.

This was the first survey exhibition of Conceptual Art in Europe but it was not so much in the content that the novelty resided but in the way it was presented. As the title suggests, the exhibition reflected on attitudes, ideas that would then become forms in artworks. This methodology reflects and adopts the very essence of Conceptual Art that emerged in the 1960s.

The exhibition aimed to show the processes and ideas of the artists at that moment, such as the eagerness to break the boundaries between the studio and the museum. The artists were given total freedom to work in the museum as if it were their own studio, which was rather unique in an institutional environment at the time. It is important to note that the position held by Szeemann was, in itself, unique as he was working in the framework of a Kunsthalle and not a Museum. When he decided to break the institutional rules, he became what is now called an independent curator, working across different institutions and ideas and following, to some extent but certainly more so than when being bound to one specific institution, his own rules and methodologies. ${ }^{31}$

31 BIRBAUM Daniel, "When Attitude Becomes Form: Daniel Birnbaum on Harald Szeemann”, Artforum, Summer 2005, p. 55. 
Harald Szeemann's position toward curatorial practice was similar to that of Pontus Hultén, as both participated actively in the creative and practical making of the exhibition at the same time. And both were interested in art that showed and generated ideas, despite its final format. It was precisely this interest that led Szeemann to curate an exhibition that opened with many works unfinished. "When Attitudes Become Form" transformed the museum into an artist's studio, where the audience could not only access the process of the artists but also be part of it, in its different phases of conception, discourse and discussion.

What was unique and pioneering about the curatorial, or the exhibition-making, practices of Hultén and Szeemann was their true interest in the processes and meanings of art. With this interest, they were inherently looking at art's relationships and critical responses to society with its changes and challenges. In other words, artists seem to be immersing themselves in the issues of life at the social, economic and political levels, while museums seem to be immersing themselves in artists' immersion practices, in a translation of a translation or an interpretation of an interpretation. This does not seem very different from any mediation work in museums; Maria Lind described mediation in relation to education and curating through the example of the Museum of Modern Art in New York. In her description, the model activated by its founding director Alfred Barr in the 1930s implied an integration of education into every exhibition. ${ }^{32}$ His main purpose was to promote a spectatorship model of "the educated consumer," in contrast to the 19th-century ideal of the spectator as a "responsible citizen." 33 Barr's display strategies implied what Maria Lind called "Points" ${ }^{34}$ to contextualize works and ideas, while putting works from different epochs and cultural contexts in dialogue, as was the case in the 1936 exhibition Cubism and Abstract Art, which put together "historical and nonWestern visual sources for 20th-century Western geometric abstraction." 35 This strategy translates a subjective point of view: Barr read the works, put them in a context which, inevitably, added his own point of view, and these works were then read by the audience which also perceived them within their own contexts.

Another very important display strategy of MoMA was, as Maria Lind put it, that it positioned itself as a mediator between industry (producers and distributors on the board of trustees) and an audience of potential art buyers. This positioning could be seen via the same display techniques in huge stores. The audience could actually buy some works in (some of) the exhibitions as if in a shop and they would be considered trendsetters, "responsible members of the emerging society of consumption." 36

In the late 1990s, Nicolas Bourriaud coined the term "relational aesthetics" ${ }^{37}$ to describe a trend in art which he had identified as convivial, participatory, collective and, many times, requiring the involvement of the audience to be complete. As the term "relational" implies, the concept referred to art that explored relationships to the other. The artworks could often be seen more as interventions and actions than objects: Rirkrit Tiravanija cooked Thai food for the staffs of museums and galleries, as at the MoMA in New York; Vanessa Beecroft created nude tableaux vivants across the world, including at the Neue Nationalgalerie in Berlin; and Philippe Parreno organized parties, such as "Snow Dancing" in 1995 in Dijon.
32 LIND Maria, Why mediate art? Ten fundamental questions of curating, Milan: Contrapunto S.R.L., 2010, p.100 33 KLONK, Charlotte. Spaces of Experience: Art Gallery Interiors from 1800 to 2000. New Haven: Yale University Press, 2009.

34 LIND Maria, Op. Cit., p.100

35 LIND Maria, Op. Cit., p.101
36 Ibidem.

37 BOURRIAUD, Nicolas. Esthétique relationnelle.

Dijon: Les Presses du réel, 1998. 
Many artists seemed to follow this idea, as translated to collective exhibitions such as the "theanyspacewhatever" in 2008 at the Guggenheim in New York. By that time, relational aesthetics were institutionalized and seen by many as what Claire Bishop called a stylistic pressure underlining skepticism about the social potential of interactive, participation-based work in general. ${ }^{38}$

From the mid-1990s to the early 2000s, curatorial, educational and administrative practices that reorganized the structures of mediumsized, under-funded contemporary art institutions would define what became known as New Institutionalism. ${ }^{39}$ According to this idea, the curatorial programs of the institutions were not only the traditional exhibitions but also an integrated program where exhibitions were conceived as one part of many, including discursive events, film screenings, radio and TV shows, reading groups, workshops and residencies. The art institution became a place where production, presentation, research, debate and community engagement would intersect in an open space where everyone is welcome to be part of the program and the social arena in which it is conceived. ${ }^{40}$

The term New Institutionalism does not come from the institutions that seem to be practicing it, as Relational Aesthetics was not a term coined by the artists who would see their works in that conceptual framework, and some institutions' professionals find it limiting, because once a concept is framed, it becomes dated. ${ }^{41}$ However, what we see more than a decade later in the practice of big and small contemporary art institutions is a continuation of the ideas and practices of what became known as the New Institutionalism.
The three examples described in the following section-Tate Modern, Tensta Konsthall and Clark House Initiative- - through narrative methods, which implied a direct observation and participation, show these ideas and practices in different ways, aiming to provide an up-to-date portrait of the changes in art institutions. While Tate is a public museum, Tensta Konsthall is a private institution, initiated as a grassroots project coinciding with Stockholm Capital of Culture in 1998, which became regarded as an art institution with the presence of Maria Lind as its director in 2003, and Clark House Initiative was initiated by two curators as a collective and private endeavour. The differences in size, history, scope and cultural contexts between these institutions allow for an understanding of diverse practices translating distinct changes of the contemporary museum, the art institution and the transformations in curatorial practices, which, in turn, imply important changes such as new forms of participation and local/global dialectics and different ways of implementing them.

\section{New forms of programming as a response to social and behavioural change: Tate Modern, United Kingdom}

Tate Modern is a public institution and one of the four Galleries of Tate. Tate's regional galleries in Liverpool opened in 1988 and in St. Ives in 1993, while the Tate Britain and the Tate Modern, both in London, opened in 1897 (under the name National Gallery of British Art, changing to The Tate Gallery in 1932 and to Tate Britain in 2000) and in 2000, respectively.

Nicholas Serota believes in the social role of art: "Tate is a champion of art and its value to society. It believes that an understanding of the visual can enrich all our lives and that artists

40 New Institutionalism, Versted\#1, (EKEBERG Jonas, ed.), Oslo: Office for Contemporary Art, 2003, p. 9-14.

41 KOLB Lucie, FLÜCKIGER Gabriel, "We want to become an institution, An Interview with Maria Lind.” On-Curating. Issue 21 December 2013, p. 29.
38 BISHOP, Claire. Artificial Hells: Participatory Art and the Politics of Spectatorship. London: Verso, 2012.

39 DOHERTY, Claire. "New Institutionalism," Skulptur Projekte Münster, (FRANZEN, Brigitte, KÖNIG Kasper, PLATH Carina, eds.) Cologne: Walter König, 2007, p. $421-422$ 
make a special contribution to the community." ${ }^{2}$ This belief has led him and his board of directors and trustees, as well as his team, to develop the scope of the collection and the ways it is displayed.

The Tate Modern is located in Southwark, one of London's most historic boroughs. Since the 15 th century and throughout its history it has been connected to many different countries through colonialism, commerce and waves of immigration and migration. Invited in the 1950s to help with Britain's post-war recovery, people of African heritage from the Caribbean settled in Southwark. Over the next five decades, more people have arrived from other countries like Vietnam, Cyprus, Sierra Leone, Liberia and Somalia, as refugees from the realities of war and conflict. From the 2000s, Southwark welcomed people from Latin America, Poland and Eastern Europe who left their countries in search of employment. ${ }^{43}$ Today, the area is facing a new change: massive, expensive buildings are being built; shops and restaurants are opening; wealthier people are buying penthouses to live in or stay in when in London. In other words, Southwark is becoming highly gentrified.

When Tate Modern opened, on 11 May, 2000, the Tate Collections consisted of artworks form South America and Western Europe only, which in the view of the director, Nicholas Serota, was a narrow perspective of a so-called global contemporary world. Seeking to represent significant developments in art, as well as the diverse world we now live in, and which the area of Southwark represents, the Tate embarked on a journey to initiate the collection as it came to be in 2016, with art from North and Latin America, the Middle East and North Africa, Africa, Russia and Eastern Europe, South Asia, and Asia Pacific.
In 2009, Tate embarked on a major expansion of the Tate Modern building, working again with Herzog \& de Meuron. The transformed Tate Modern opened on 17 June, 2016, widely increasing gallery space, which provides new opportunities to show the collection in different ways.

Even though the scope of the collection is broad in terms of nationalities and represents media as diverse as photography, film, installation, painting, sculpture and performance, it is not conceived or divided into nationalities or media, but into themes that the curators find relevant to the times we are living in at local, national and international levels. The team of curators meets every two weeks to discuss ideas and ways of displaying the artworks in thematic and conceptual constellations that are relevant across the collection in relation to society. The collection is shown in different thematic areas and rooms throughout the building. In "A View from Tokyo: Between Man and Matter," "A View from Buenos Aires: Media Networks at Tate Modern," "A View from São Paulo: Abstraction and Society" and "A View from Zagreb: Op and Kinetic Art," the works reflect on the realities of city centres that have existed in a time and context rather than looking into only the usual suspects such as Paris, London and New York. With these views, the collection's display reflects on the diversity of the world and also of London.

The mission of Tate has been changing in a cumulative process: in 1998, the aim was to democratize access to art, while in 2009 it became to provoke dialogue about art, and in 2015 both aims were joined by the goal of activating people through art. An example of this cumulative mission is the growth of the program that is not exclusively dedicated to exhibitions and displays of the collection but also to the growth of experiences in the website, to lasting local and international

43 Southwark Council, History of Southwark. Southwark's world connections. http://www.southwark.gov.uk/ info/200159/history_of_southwark/1025/southwarks_ world_connections, Retrieved July 2016
42 Tate, Tate's vision: Championing art and its value to society. http://www.tate.org.uk/download/file/fid/101667, Retrieved July 2016 
partnerships, to the creation of Tate for All, to activities for children and young adults, and also to community programs, such as the Tate Modern Community Garden, where citizens joined the artists and the Tate's staff to create and maintain a garden.

This change in the mission of Tate, which fosters the transformation of the museum's physical and conceptual spaces as well as its mediation practices, responds to the internal discourses of the art field: if we think of the art being produced in the late 1990s, we will think of examples such as Parreno's parties and Tiravanija meals, which Nicolas Bourriaud framed within the concept of relational aesthetics, which imply participation in an active relationship with the audience only-artists and audience would be part of the creative process and the reception of works.

Being a public museum, Tate is, above all, open to the public, a choice that has consequences for the institution's identity as well as for its program. Many of the activities and events that take place at the Tate Modern are not organized by the curators and the staff or even authorized by the Tate but they are still regarded by the organizers and the public as activities that take place at Tate and are part of it in various ways. With a public mission of being open to the community and publicly praising freedom of speech, interventions such as the Remain Campaign took place at Tate Modern without permission or participation from the Tate's staff. Like other landmarks across Britain, the Tate Modern was illuminated on the night of 21 June, 2016, with Union Jack colors with the projection "Vote Remain." It was an independent act that the Tate, as a public institution, could be part of, but that the art audience seemed to believe they would agree to.

Questions of diversity and inclusion appear across the program while challenging the established practices of the institution. Tate created the Tate for All, a department dedicated to the relationship between diversity and inclusion with the audiences, staff and institutional structures of the Tate. The program of Tate Modern aims to reflect precisely the social differences raised by a diverse world where inclusion is needed, not only legally to prevent discrimination (which is the case of Tate that responds to The Equality Act, 2000), but also to reflect the creative core of showing the different perspectives that characterize the existing voices of the world, including those that have been silenced by war and conflict.

Tate for All, Tate Community Gardens and the Young Adults programs are all implemented within the "Interpretation department"- the equivalent of the educational or mediation departments in other big institutions such as the MoMA, Gulbenkian and Guggenheim, to name a few. The choice of the word "interpretation" seems to fall short of what is done at the Tate. Rather than interpreting the works, it is about telling the contexts (from war scenarios to urban conditions of a metropolis such as Tokyo) in which the works were produced and their stories in factual descriptions that are comprehensible both for a museum professional and for someone without any knowledge of art. The challenge is to make these actions appealing both for the professionals and the general audience: rooms with explanations of what the caption means, from the title of the work to the name of the artist and the medium used, might be interesting for someone with little or no knowledge of the arts, but for an arts professional, this might sound reductive. However, it is in the combination of different mediation in a diverse program, encompassing popular exhibitions (such as "Jackson Pollock: Blind Spots" in 2016 and Wolfgang Tillmans' solo show in 2017) and niche events (like Light and Dark Matters, a series of events spread over twenty-four hours, which brought together leading artists, scientists and philosophers) that Tate seems to operate best in the translation of the internal discourses of the art field.

\section{The museum as a local player: Tensta Konsthall, Sweden}

Unlike Tate Modern, Tensta Konsthall is a private institution and does not have an art collection. It is an art centre dedicated to the production and exhibition of contemporary 
art, located in Tensta, a district in SpångaTensta borough, Stockholm, twenty minutes on the subway from the city centre.

For any non-Swedish visitor, the feeling upon entering Tensta is uncanny; it does not feel like Sweden as we know it. Sweden continues to be perceived by many, especially outsiders, as the perfect portrait of social democracy. Yet this image is closer to a long-gone history than to the current situation, which is the child of the neo-liberalization that the country has faced since the $1980 \mathrm{~s} .{ }^{44}$ Today about 39,000 people live in Tensta, of whom almost $60 \%$ have a foreign background, facing numerous challenges, including problems of identity and marginalization, and socio-economic challenges. ${ }^{45}$ Since the 1980 s, large waves of migrants and newcomers have settled in this suburb of Stockholm mainly because of the more affordable rents, and other immigrant communities were already residing there. ${ }^{46}$

At Tensta Konsthall, it is not uncommon to see the same high-profile artists that one can find in other international art institutions. What is unique at this konsthall is the ongoing inquiry into what contemporary art is and can be, and the way each activity is produced and communicated to the local audience. That is the case with the mediation program, a very dear aspect to the konsthall as shown by the series of seminars titled "What does art mediation do?" in the spring of 2012. In collaboration with the Department of Visual Arts Education and Curatorlab, Konstfack, these series explored the ways in which the audience can meet art and take an active role in it.
Like Tate Modern, Tensta Konsthall deliberately sought to create a program different from the education or pedagogical departments of bigger or more conventional art institutions, hence the wider denomination of mediation program. The goal of the mediators at Tensta Konsthall is not just to create programs parallel to the exhibitions but even more to do research with a focus on art as much as on the Tensta suburb. It is then a program exploring methodologies that can be relevant in Tensta, while maintaining the high quality expected by the contemporary art public. Reflections on the grand-narratives ${ }^{47}$ that shape this Stockholm suburb, such as ideas of gang violence and crime associated with it, are usually the departure point for projects initiated within the mediation program, which often includes collaborations with local organizations, such as a separatist fashion project created for young girls from Ross Tensta gymnasium. By partnering with local organizations in overcoming the grand-narratives associated with the site, Tensta Konsthall is co-creating an image of a new Sweden, a role that the (once social-democratic) Swedish system seems to be dismissing.

In 2015, in the frame of its mediation program, Tensta Konsthall hosted The Silent University, an autonomous knowledge-exchange platform initiated by Turkish artist Ahmet Ögüt during a yearlong residency at Tate in partnership with Delfina Foundation. The platform is made by refugees, asylum-seekers and migrants who have had an academic career in their countries of origin but are unable to continue their career paths due to a variety of reasons related to their new condition. Led by a group of lecturers, consultants and researchers, the platform uses the format of an academic program to research

46 ANDERSSON, Roger, BRÅMÅ Åsa, "Selective migration in Swedish Distressed Neighborhoods: Can Area-based Urban Policies Counteract Segregation Processes?" Housing Studies, Vol. 19, n ${ }^{\circ} 4,2004$, p.518

47 By grand-narratives here I mean David Boje's concept of stories that are told by one instead of the small stories told by many. These grand-narratives are usually prejudiced ideas of a determined reality that, by being repeated, become regarded

as absolute truths.
Frieze, New Sweden. Re-evaluating modernist housing article/new-sweden, Retrieved June 2016

45 Interpeace. Voices from Tensta. Report of a pilot project in Tensta, a suburb of Stockholm. May 2015. http://interpeace. se/wp-content/uploads/2015/10/Voices_From_Tensta.pdf, Retrieved May 2016 
and address key themes of our times, including personal reflections such as the meaning of being a refugee and asylum-seeker.

Tensta Konsthall is embedded in the daily life of Tensta as it is self-understood and positioned as a local player by being part of the local social and economic infrastructure. One of the most practical and visible examples is the Tensta Café, the first aspect of the building the visitors encounter upon entering the arts centre. The café is run by the local social company Xpandia Vision and hires only locally and buys only local services. It has also been the setting for community-organized activities such as the Tea and Coffee Salons, with Tensta Hjulsta Women's Centre and the Konsthallsklubben (Gallery Club). Young girls who then attended a local school initiated this Club in 2011; they would meet informally at the Tensta Café, the only café in the area, simply to speak and hang out. This soon caught the attention of one of the mediators, and a Club was set up to discuss and make art projects related to identity-one ity of Tensta-together with artists and the konsthall's staff in Tensta and other places.

In order to learn from and share experiences with other small to medium visual arts institutions operating within residential and peripheral areas of specific local communities, while aiming for an international scope, Tensta Konsthall, together with Casco (Utrecht, The Netherlands), CAC (Brittany, France), Les Laboratoires d'Aubervilliers (Paris, France), The Showroom (London, United Kingdom), CA2M Centro Dos De Mayo (Madrid, Spain), Parasite Museum of Contemporary Art (Ljubljana), and the Israeli Centre for Digital Art (Tel Aviv, Israel) created the network Cluster in 2011. In the following year, inspired by Cluster, the Swedish network Klister (glue) was formed with small and medium-sized contemporary art institutions. The aim was to reflect and act on the role of smaller art institutions in society or, in other words, how to become local players: in 2013 Klister arranged a series of meetings and discussions targeting local politicians and bureaucrats, and in 2014 commissioned a report on the conditions for its members.

\section{Shared curatorial practices of collaboration at local and global levels: Clark House Initiative, India}

Clark House Initiative is a private curatorial collaborative and a union of artists based in Bombay, founded by Zasha Colah and Sumesh Sharma in 2010. The Victorian building that houses Clark House was founded in conjunction with two museums and a cinema and, before the establishment of the union, it was the site of various endeavours: an office of pharmaceutical research, an antiques shop and the shipping office of the Thakur Shipping Company which had links to different countries in the Middle East, Eastern Europe and Japan. When Zasha Colah and Sumesh Sharma established Clark House Initiative, they were very aware of the context and the history of the site and were committed to continuing its legacy through curatorial practices that would experiment with the histories of research, ideas of time and a commitment to internationalism. All of these would share a concern with freedom and its different levels of meaning, which is a dear theme to India with its colonial past, but also on a global scale, in times of worldwide social and economic crisis.

In 2010, when Clark House Initiative was founded, the methodology used was coherent to their title of collaborative. Instead of inviting or commissioning one or a group of artists for an exhibition, under a pre-determined curatorial umbrella, they invited entries for a film festival from the Northeast, the "Black Rice Film Festival." The responses showed the variety of the area and included documentaries about the region's gastronomy, travelogues and political films. Choosing to open an arts space with a film festival made from the responses they would get was a bold option. It was much more difficult to raise the funds for the space, but it was their conscious choice to establish themselves as independent, collaborative and free to protest, like the political films they screened in the opening event. 
Freedom is at the core of Clark House Initiative: they did not want to be a conventional institution funded by sponsors and patrons or to be a commercial gallery. They wanted to create an alternative economic model, to exist in and outside their space in Colaba and to create political initiatives that questioned the existing social system in India.

Collaboration is key to their activities and to the ways they express the idea of freedom at conceptual and practical levels. Their curatorial practice and ethos is based in sharing ideas, knowledge and resources and, in order to make their activities viable in an unconventional way, partnerships are crucial, a trope that is being used more and more across the world in both small and larger art institutions, despite their missions and methodologies as observed in Tate and Tensta Konsthall.

Following the collaborative and network approach of Clark House Initiative, the projects curated by them take place in different locations across India and the world, as was the case of the initiative with Groupe Dix10, a French artist collective and various Indian artists. In 2015 they organized the international Festival of Arts in the City of Bombay, the Liberty Taken, in association with the Institut Français, Osianama at Liberty, Sir JJ School of Art and Stedelijk Museum Bureau Amsterdam, with the support of the Kadist Art Foundation, Paris. The Project is seen as collaborative, where Osianama at Liberty opens its space to interventions that are demonstrative towards engaging a young audience of artists and students with cinema, creating a critical engagement between cinema and the visual arts. The Festival took place in different spaces in Bombay: the Osianama at Liberty Cinema, Clark House and Sir JJ School of Art, and a variety of private and public spaces in the city, through ephemeral and unexpected situations and micro-events.
Clark House Initiative praises internationalism and is also getting international attention and exposure for its curatorial practices and methodologies, which are local, while operating in an international scope. In the short history of this collaborative endeavour, they have been invited to various research residencies, such as the International Studio and Curatorial Program New York; to international collaborative projects such as the research into the imagining of affinities of Bombay and London, with The Showroom; and exhibitions in different countries, such as "What is human Becomes Animal?" at the invitation of the New Galerie, in Paris.

Besides participating in the international arena by making part of their program outside India and applying many of the international methodologies of today-collaboration, co-production, partnerships, residencies and the like-Clark House Initiative also invites artists from other countries for exhibitions and residencies in their home country. In 2016 they welcomed French artist François Mazabraud in residency. This allows for a discussion of the same issues through different cultural lenses, an approach which is naturally wider-and possibly raises as many points of conflict as of agreement - than looking at the same issue through only the same references and histories. This is precisely where the collaborative focus of the Clark House Initiative is rich and meaningful at both local and global levels.

\section{Conclusions}

Art has been reflecting the worlds we live in since its inception. In the same way, art museums have been addressing the concepts that art implicates, either in an indirect way of displaying artworks in traditional collective or solo exhibitions or in a more direct and participative way, through a series of discursive activities and events that are all part of the same 
ideas. In other words, "the function of the museum is the function of art itself. It shows how art changes with time." ${ }^{48}$

The 21 st century is witnessing social and economic crisis, environmental disasters, wars, a flow of migrants and refugees trying to escape their harsh realities, a return to political systems that we have already watched collapsing, democracies at risk of falling, countries that once welcomed migrants closing their doors and becoming more and more nationalistic, and a global fear of the unknown and the Other. Parallel to this, the world is evolving digitally and technologically, humans have more resources to deal with challenges and distances are shortening, in ways that we could not have envisioned one hundred years ago.

The methodologies of art, both at conceptual and practical levels, change with social changes as well as with the rise of new technologies. Since the 1960s, artists have been moving away from the confinement and solitude of museums, as well as to the streets and wherever daily life happens, from cafés to neighbourhood cinemas and favelas. If the core of the museums-artworks-has changed methodologies, conceptual frames and shapes (with many not having a physical form but being immaterial, ephemeral and non-visual), the museums' strategies and methodologies of displaying, collecting and communicating art with the audience had to change as well.

The challenges and possible futures of the art museums are not a new debate, as history shows. In 1969 and 1970, professionals of museums of contemporary art met at UNESCO to discuss the "Problems of the museum of contemporary art in the West." ${ }^{49}$ In 2016 Tate organized the Tate Intensive: Making Tomorrow's Art Museums, a program

of activities, discussions and visits led by senior Tate staff, with the participation of a group of culture professionals from across the globe, to share knowledge and exchange ideas concerning both current practices and new trends at contemporary art institutions. Interestingly, the challenges raised today are not that different from the ones that emerged in the 1970s.

What seem to be changing are the ways that the challenges, posed both by the social and the art systems, are being conveyed. Art museums are seeking to create emotional experiences that inspire visitors to take action through art rather than educating or asking for a collaborative participation only. Art museums seem to be moving away from traditional exhibition-making and display to emotion-driven and museum experiences which provide opportunities for engaging proactively in the world where they live. In other words, it seems that museums are adopting Joseph Beuys' famous motto "Everybody is an artist," in what can be regarded as the epitome of the empowerment of the individual. With empowerment comes the responsibility that each individual has towards the collective social realm we all live in. 


\section{Les musées d'art: situation actuelle.}

Dans le manifeste Pour un art révolutionnaire indépendant, André Breton et Diego Rivera (1938) soutenaient que l'art ne pouvait être révolutionnaire et avoir d'effet dans la société que s'il devenait indépendant de toute construction sociale. Cinquante ans plus tard, Nicolas Bourriaud dans son concept d'" esthétique relationnelle" constate une certaine affinité avec ces mêmes idées dans la production artistique inspirée ou basée sur l'observation de relations humaines dans leur contexte social et culturel ${ }^{1}$.

Bourriaud considère les artistes non pas comme des producteurs, mais plutôt comme des facilitateurs ou des médiateurs axés sur l'art de l'échange et de la collaboration, comme Joseph Beuys qui avait au cours des années 1970, reconnu le pouvoir créateur des individus à changer le monde.

D'un point de vue sociologique, si nous considérons l'art comme un système social (Luhmann, 1984), notre compréhension de celui-ci sera d'ordre perceptuel. Suivant cette idée, le rôle de l'art serait de montrer le monde tel qu'il est, et non comme il devrait l'être. Par le biais de la subjectivité de la perception, l'art révèle les différentes façons dont nous regardons - ou percevons - le monde dans lequel nous vivons. La pratique de l'art contemporain est de plus en plus similaire à celle de la recherche en ce qu'elle plonge dans les situations courantes pour ensuite émerger avec une série de possibles traductions visuelles de ces situations.

Les musées et les pratiques curatoriales s'occupent par définition, d'art. Mais comment leurs activités de collectionnement, de conservation et d'exposition se positionnent-ils par rapport à ces situations? En d'autres termes, comment les musées d'art contribuent-ils à élever l'art à faire ce qu'il fait de mieux?

Dans un monde caractérisé par des défis sociaux, économiques et politiques, les musées d'art semblent s'éloigner des méthodologies épistémologiques et des pratiques curatoriales fondées sur l'hypothèse que les collections détiennent une sorte de vérité absolue et linéaire, pour se rapprocher d'un lieu où les collections sont perçues en tant que strates de réalités basées sur des récits non-linéaires, où le public muséal participe de manière active et critique. L'accent mis sur le rôle des musées de même que les modes de collectionnement, de conservation et de diffusion de l'art institutionnel s'intensifie à la fois dans le contexte des expositions réalisées dans des espaces institutionnels et en dehors de ceux-ci. C'est le cas de nombreux projets participatifs exigeant d'autres moyens de communication et de médiation que les projets conventionnels. 
Trois études de cas réalisées au Tate Modern au Royaume-Uni, le Tensta Konsthall, en Suède et la Clark House Initiative en Inde, serviront à analyser les possibilités et les défis relatifs au rôle des musées d'art. La méthode employée associe les récits qui composent leurs histoires respectives, (Boje, 2001), aux interrogations suivantes: Comment les nouvelles formes de programmation relient et répondent aux changements sociaux et comportementaux? Qu'advient-il des pratiques de médiation et de conservation quand elles sont placées dans le contexte d'une communauté locale? Quelles pratiques communes de conservation peuvent être utilisées localement et globalement? Comment l'art peut-il être diffusé pour permettre à l'individu de réfléchir de façon critique sur luimême et son existence par rapport à la société environnante? Un musée peut-il agir en tant qu'acteur local?

L'analyse compréhensive de ces questions mènera vraisemblablement à des réponses et à des expériences potentielles concernant les pratiques actuelles et les nouvelles tendances qui modèlent les musées et les centres d'art au XXI ${ }^{\mathrm{e}}$ siècle. 